\title{
Hydrogeological vulnerability in Jacó coastal aquifers, Central Pacific, Costa Rica
}

\section{Vulnerabilidad hidrogeológica en la zona costera de Jacó, Pacífico Central, Costa Rica}

\author{
Alicia Gómez-Cruz ${ }^{1}$ \\ Helga Madrigal-Solís ${ }^{2}$ \\ Christian Núñez-Solis ${ }^{3}$ \\ Hazel Calderón-Sánchez ${ }^{4}$ \\ Pablo Jiménez-Gavilán ${ }^{5}$ \\ Universidad Nacional, Costa Rica
}

\begin{abstract}
In the last two decades, the Central Pacific of Costa Rica experienced a strong growth in urban and tourism development. If not regulated, this development can result in a pressure to groundwater resources and, therefore, a threat in terms of quality and quantity. In this study, a hydrogeological vulnerability map of Jacó aquifers was performed, by the GOD method. Geological profiles were elaborated, and field verification was performed. It is confirmed that, in the study area, two aquifers are found: a) a detritic, porous, unconfined coastal aquifer, settled in the Jacó alluvial plain and, b) an aquifer in the basaltic fractured rocks of the Nicoya Complex, unconfined in the mountainous zone and underlying the detritic formation in the central area, where the groundwater is integrated to that of
\end{abstract}

1 Licda. Alicia Gómez-Cruz. Laboratorio de Hidrología Ambiental. Escuela de Ciencias Biológicas. Universidad Nacional de Costa Rica. agomezcruz@gmail.com

2 MSc. Helga Madrigal-Solís. Laboratorio de Hidrología Ambiental. Escuela de Ciencias Biológicas. Universidad Nacional de Costa Rica. helga.madrigal.solis@una.cr

3 MSc. Christian Núñez-Solís. Laboratorio de Hidrología Ambiental. Escuela de Ciencias Biológicas. Universidad Nacional de Costa Rica. christian.nunez.solis@una.cr

4 Licda. Hazel Calderón-Sánchez. Laboratorio de Hidrología Ambiental. Escuela de Ciencias Biológicas. Universidad Nacional de Costa Rica. hazelcalderon@gmail.com

5 Dr. Pablo Jiménez-Gavilán. Departamento de Ecología y Geología. Facultad de Ciencias. Universidad de Málaga.pgavilan@uma.es. 
the detrital aquifer. The zone of the alluvial aquifer resulted in a medium vulnerability index, whereas the mountainous areas in a low vulnerability. Management recommendations were proposed.

Keywords: Coastal aquifer; hydrogeological vulnerability; GOD index; fractured aquifer; groundwater protection.

\section{Resumen}

En las últimas dos décadas, el Pacífico Central de Costa Rica experimentó un fuerte aumento en el desarrollo urbanístico y turístico, lo que representa una mayor amenaza a la calidad del agua subterránea. El objetivo de este estudio fue el generar una propuesta del Mapa de Vulnerabilidad Hidrogeológica de los acuíferos de Jacó, utilizando la metodología GOD. Para esto, se elaboraron perfiles geológicos y se realizó comprobación de campo. Se evidencia que el área de estudio está conformada por a) un acuífero costero detrítico, poroso y libre, albergado en la planicie aluvial de Jacó y, b) un acuífero fracturado en las rocas basálticas del Complejo de Nicoya, libre en la zona montañosa y subyaciendo la formación detrítica en la zona central, donde el agua subterránea se integra a la del acuífero detrítico, conformándose en un mismo acuífero. La zona del acuífero aluvial obtuvo una vulnerabilidad moderada, en tanto que el fracturado una vulnerabilidad baja. Se propusieron recomendaciones de manejo.

Palabras clave: acuífero costero, vulnerabilidad hidrogeológica, GOD, acuífero fracturado, protección del agua subterránea.

\section{Introduction}

At the global level, access to drinking water has been threatened due to an increase in demand to satisfy a greater number and variety of anthropogenic activities, greater pollution load and an irrational use of the resource (Llamas and Custodio, 2003). Based on development models (Foster, 1992), the World Bank (WB) has recommended the mapping of aquifer threats, vulnerability and risk cartographies, as a measure for protecting groundwater quality (Foster et al., 2007). The intuitive concept of aquifer vulnerability dates back to the 1970s (Albinet and Margat, 1970); subsequently, it found widespread use in the 1980s (Foster and Hirata 1988). According to Foster et al. (2007), the concept of groundwater vulnerability depends on the characteristics of the strata that separates the unsaturated zone from the saturated zone. These characteristics determine the tendency or probability of a given pollutant reaching a specific position within the aquifer system, after its introduction on the ground.

In Costa Rica, in the past last decades, environmental policies aimed at reinforcing the protection and rational use of natural resources have emerged and consolidated. Nevertheless, water resource management faces great challenges, which must be overcome with efficient actions to 
Alicia Gómez-Cruz - Helga Madrigal-Solis - Christian Núñez-Solís

Hazel Calderón-Sánchez - Pablo Jiménez-Gavilán

Hydrogeological vulnerability in Jacó coastal aquifers, Central Pacific, Costa Rica.

guarantee environmental quality and sustainability of the groundwater resource (Reynolds and Fraile, 2002). For this reason, as of 2008, the government of Costa Rica ruled for the development of hydrogeological vulnerability studies and their inclusion in urban development regulations of each canton of the country, according to the GOD method (Groundwater Hydraulic confinement - Overlaying strata - Depth to groundwater table). The GOD method considers two basic factors: the degree of hydraulic inaccessibility of the saturated zone and the attenuation capacity of the overlying strata to the saturated zone (Foster and Hirata, 1991). This methodology uses the following parameters (Foster et al., 2007): degree of hydraulic confinement $(\mathrm{G})$, characteristics of substrates of the unsaturated zone or confining layers, taking into account lithological aspects and the degree of consolidation $(\mathrm{O})$ and; distance to water, considered as the depth at the water table or the roof of the confined aquifer (D). The degree of hydraulic confinement refers to whether the aquifer is free, confined or semi-confined (Foster et al., 2007).

The supply of drinking water has been a key factor for the development of coastal communities. However, the disorderly growth in the maritimeterrestrial zone of the Central Pacific region of Costa Rica reveals the limited follow-up to existing regulations (Estado de la Nación, 2007). In addition, in recent years, rapid urban and tourism development has spurred in this area (Barrantes, 2004). According to the National Institute of Statistics and Censuses (INEC, 2012), the canton of Garabito, to which the community of Jacó belongs, has presented the highest population growth rate in the country during the last 30 years, which could lead to an increase in the load of pollutants released into the environment (Orozco, 2015).

On the other hand, the shallowness of the phreatic level, in some sectors (Arias and Morera, 2002), implies that anthropic activities represent a threat to the quality of groundwater. Due to the rapid urban and tourism growth in the city of Jacó, it is necessary to have a tool that contributes to territorial ordering for the protection of groundwater resources, which are widely used for human consumption and other productive activities. For this reason, the objective of the present study is to elaborate a Hydrogeological Vulnerability Map (HVM) proposal for this geographical region. 


\section{Study area}

The study site (Figure 1) is located in the district of Jacó, canton of Garabito, province of Puntarenas, Costa Rica, between the geographic coordinates $9^{\circ} 35^{\prime} 40.66^{\prime \prime}-9^{\circ} 40^{\prime} 34,647^{\prime \prime}$ north latitude and $84^{\circ} 38^{\prime} 48,466^{\prime \prime}$ $84^{\circ} 34^{\prime} 27,373^{\prime \prime}$ west longitude, and between coordinates $1061000 \mathrm{~m}$ - $1070000 \mathrm{~m}$ north and $429000 \mathrm{~m}$ - $437000 \mathrm{~m}$ east in the Mercator Transversal Projection System for Costa Rica (CRTM). The study area is delimited by a hydrographic basin labeled Jacó, a name given to the study area under analysis, with an extension of $47 \mathrm{~km}^{2}$; it consists of three micro-basins that belong to the Pueblo Nuevo (Mona), Copey and Naranjal rivers. An aquifer is located in the lower and middle part of these microbasins, settled in unconsolidated deposits, with an approximate extension area of $15 \mathrm{~km}^{2}$. The remaining area is mainly composed of basalts and sedimentary rocks, where a fractured aquifer is found. These rocks are located in the mountains (Figure 2).

Figure 1. Study area location map, Jacó, Puntarenas, Costa Rica.

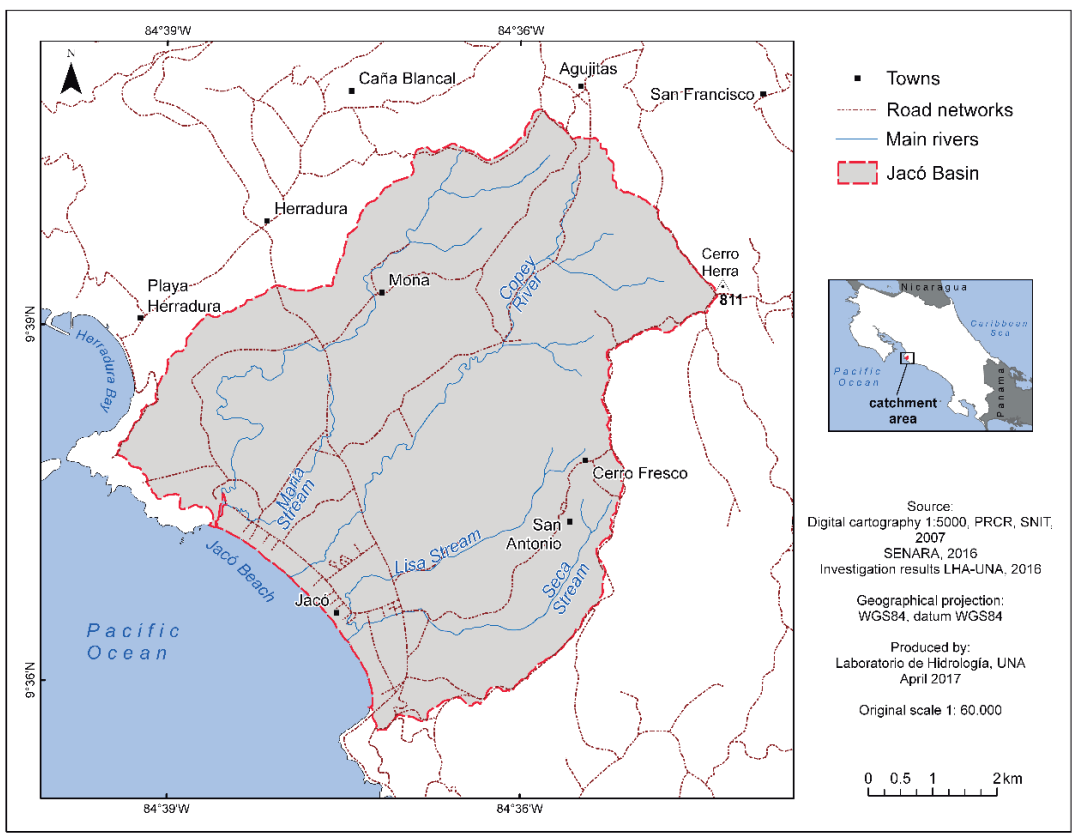


Figure 2. Study area geological map, Jacó, Puntarenas, Costa Rica. Modified from Arias (2003). Redefinition of the Tulín Formation (Maastrichtian-Lower Eocene) of the Central Pacific of Costa Rica.

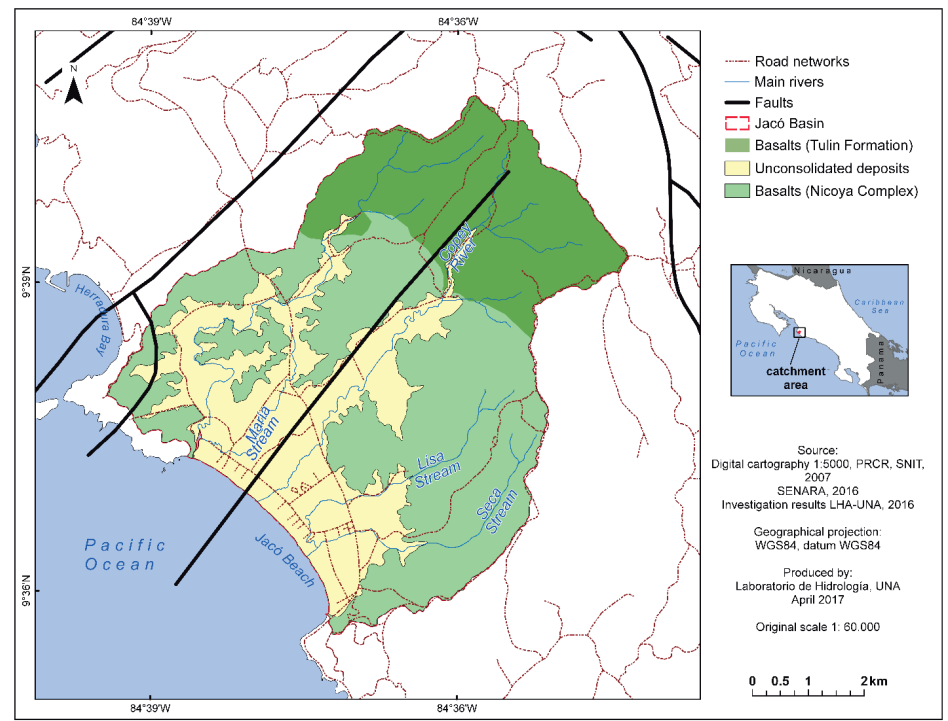

\section{General characteristics}

The dry season extends for five months, from December to April, January being the driest, while the rainy season includes the months of May to November and the rainiest month corresponds to October. According to the published 2014 database of the National Meteorological Institute of Costa Rica, between 1997 and 2013, the Jacó metereological station registered an average maximum rainfall of $616.6 \mathrm{~mm}$ in the months of October; the minimum precipitation occurred in the month of January, with an average of $25 \mathrm{~mm}$.

\section{Geological aspects}

The study area is comprised of three types of lithostratigraphic units that are clearly distinguishable from each other: a) basalts from the Nicoya Complex, including radiolarite, limestone, sandstone and lulite rocks, b) basalts associated with the Tulín Formation, and c) unconsolidated deposits (Figure 2). 


\section{Nicoya Complex}

Dengo (1962) defines the Nicoya Complex as a series of intensely folded rocks, consisting of basalts, sedimentary and intrusive units. Kuypers (1980, cited in Sprechmann et al., 1984) indicates that ambiguity in its definition exists because the series of overlying rocks are locally folded and also due to the presence of basaltic extrusions. Therefore, different lithologies are included within the unit and, consequently, the attributed age varies. Based on the aforementioned arguments, Kuypers (1980, cited in Sprechmann et al., 1984) and Baumgartner (1984) propose a stratigraphic subdivision for the Nicoya Complex, which consists of two units, Matapalo and Esperanza. Arias (2003) refers to the basalts that have been associated with the Nicoya Complex as basalts of the Caribbean Oceanic Plateau (COP); these basalts are the oldest rocks.

The Matapalo Unit is $150 \mathrm{~m}$ thick; it is characterized by being formed by oceanic tholeiitic basalts covered by radiolarites, with a minimum thickness of $40 \mathrm{~m}$. The assigned age spans from Callovian to the Aptian (Kuypers, 1980, cited in Sprechmann et al., 1984). Its contact with the overlying Esperanza unit is not clearly visible (Kuypers, 1980, cited in Sprechmann et al., 1984). In the Esperanza unit, consisting of tholeiitic basalts and ophiolitic diabases, gabbro rocks, plagiogranite stocks and some radiolarite, intercalations up to $3 \mathrm{~m}$ in the upper part of the unit are common. The assigned age is Santoniense (Kuypers, 1980, cited in Sprechmann et al., 1984).

In the study area, the geology in mountains is composed of basalts and sedimentary rocks of the types: sandstone, lutite/shale, radiolarites and limestone, that are associated with the rocks of the Nicoya Complex (Arias and Morera, 2002). These lavas, of basaltic composition, are of a black coloration and, by their origin, have a texture of pillowy folds, which characterizes them. On the surface, they are weathered and easily confused with coarse sands.

The radiolarites of the Nicoya Complex are part of the Matapalo Unit, from the Upper Jurassic-Lower Cretaceous. They are rocks of pelagic origin, from fine to very fine grain, stratified, quite hard and versicolor (Agudelo, 2005). They are related to flints and jaspers and are very often associated with iron-manganese mineralization, the result of hydrothermal alteration in ocean beds from exhalative volcanism, either in disseminated 
form or in nodules. The radiolarites overlap disconformingly the basalts and is crossed by numerous intrusive gabbroid to diabasic bodies. It presents a strong tectonic deformation (isoclinal-chevron folds) and a high degree of faulting (Agudelo, 2005).

\section{Tulín Formation}

Arias (2003) suggests that the Tulín Formation, (MaastrichtianLower Eocene), is composed of $95 \%$ basalts, which are presented as pillow castings; these basalts have interspersed epiclassic sediments, pyroclastic, gabbros, and olivine cumulites. It is a younger formation than COP, whose rocks constitute the basement of the Tulín Formation.

\section{Unconsolidated deposits.}

All recent deposits associated with gravity deposits at the foot of the mountain or colluviums and those related to alluvial processes belong to this unit. Also, those deposits of sandy materials with marine influence. Deposits associated to materials dragged by fluvial action or gravity action, are generally fragments of rocks of diverse sizes and composition immersed in a silt-clay sandy matrix. Towards the foot of the mountains, the blocks of fragments are larger and sub-rounded to rounded, while toward the lower part of the basin the fragments are smaller, since they have been dragged a greater distance, as evidence by their lower degree of angularity (Arias and Morera, 2002).

\section{Theoretical-conceptual framework}

The estimation of the GOD vulnerability index (Foster and Hirata, 1988) involves a series of specific stages. First, identify the degree of hydraulic confinement of the aquifer and assign an index to this parameter on a scale from 0.0 to 1.0 . Second, specify the characteristics of the substrate overlying the saturated zone of the aquifer in terms of: a) degree of consolidation (taking into account the probable presence or absence of permeability by fissures) and, b) type of lithology (indirectly considering effective porosity, matrix permeability and moisture content in the unsaturated zone or specific retention) and, assigning to this parameter an index on a scale from 0.4 to 1.0. Third, estimate the distance or depth 
to the water level (in unconfined aquifers) or depth to the ceiling of the first confined aquifer and subsequently assigning an index on a scale from 0.6 to 1.0. In this regard, the danger of groundwater contamination is later defined as the probability of groundwater, in the upper part of an aquifer, becoming contaminated to an unacceptable degree relative to water quality standards as imposed by the activities developed on the surface of the overlying terrain (Foster and Hirata, 1988, Foster et al., 2007).

Thus, instead of applying universal controls over the potentially contaminating activities taking place on the territory and effluent discharges, it is more effective (and less harmful to economic development) to modify the type and level of control in accordance with the attenuation capacity of the aquifer. This is the basic premise behind the concept of contamination vulnerability in aquifers and what leads to the necessity of its mapping (Foster et al., 2007).

\section{Methodological framework Geological profiles}

In the study area there are 57 private wells registered and four public supply wells belonging to $A y A$. Of 57 private wells, only 21 include a lithological description in their drilling reports. These reports were retrieved in October 2016 from the institutional archive of the Directorate of Water Research and Management of the National Groundwater, Irrigation and Drainage Service (SENARA) and the Water Directorate of the Ministry of Environment and Energy (MINAE). Based on this information, at least 11 geological profiles were drawn, from which the four most representative profiles were chosen to determine the relationship between the geological units. A profile was drawn with direction from southwest to northeast, the second profile from northwest to southeast, crossing the lower basin sector, and the third from northwest-southeast, crossing the sector of the upper basin.

\section{Differential gauging.}

To define the hydraulic relationship between surface and groundwater, two differential gauging campaigns were planned, one during the dry season and the other in the rainy season, in the main rivers and 
streams of the basin. Differential gauging has been widely used in various climatic situations to perform flow estimates, for example, in Andreo et al. (2004) and Barberá and Andreo (2015). For the selection of gauging sites, consideration was taken not to include those influenced by inflows or outflows of water from other water bodies, and if so, such water flows were quantified to assess the hydraulic relationship between the water bodies (rivers and streams) and the aquifer. In November 2013, during the rainy season, gauging was carried out in 18 sites; in March 2014, dry season, in 12 sites. The difference between the two campaigns resides in that six of points gauged during the rainy season were dry at base flow. Once the flow at each gauging point was calculated, the influent and effluent sections of the river were defined.

\section{Vulnerability map}

The GOD method (Foster et al., 2002) was used to characterize the vulnerability of the aquifers in the study area. To obtain the vulnerability values in each of the layers comprising the GOD method, a review was made of the Geological Map of Costa Rica (Denyer and Alvarado, 2007), Tectonic Atlas of Costa Rica (Denyer et al. al., 2003), and a study carried out by Arias (2003) as well as available digital cartography and orthophotography (PRCR, 2007) data. In addition, field corroboration of the area's geology was made, correlating the observed outcrops with the descriptions made by the mentioned authors. Also, lithological information of the wells present in the area was compiled from the drilling reports filed in SENARA (National Service of Groundwater Irrigation and Drainage) and in the Water Directorate of the Ministry of Environment and Energy (MINAE), as well as drilling/perforation data from $A y A$ wells, to estimate the thickness of the unsaturated zone and the depth of the aquifer roofs. Finally, the resultant geological profiles elaborated in this investigation were used to improve the understanding of the conceptual hydrogeological model. A Geographic Information System (GIS) was used to integrate the information required to estimate the values in each layer of the GOD method. Once the vulnerabilities in the study area were defined, a matrix was elaborated with the suggested activities for each zone in accordance with its particular vulnerability and consideration of the activities developed in the region. 


\section{Results \\ - $\quad$ Hydrometry}

During flow measurement campaigns, the absence of water intakes for irrigation, reservoirs or any other water use along the the stream was corroborated in the field. In this way, the influent-effluent character of the studied streams was confirmed. In the rainy season, the Mona Stream had a section in the central sector of its route where the flow decreased from 79.9 to $14.7 \mathrm{l} / \mathrm{s}$. This flow reduction indicates that in this sector the stream behaved as an influent and the section that continues to its outlet as an effluent (Figure 3). The Copey River, during the rainy season, behaved as an effluent for most of its course, except for the middle sector, where the flow decreased from 133.2 to 112.9 1/s. The Seca Stream, also during the rainy season, had an effluent behavior, except in its mouth, where its flow changed from 99.6 to $52.4 \mathrm{l} / \mathrm{s}$, becoming an influent stream in that site (Figure 3). During the rainy season, the influent-effluent behavior of the rivers along its course showed that the aquifer has a depth at the same level as the groundwater above the river bed thus the aquifer is capable of feeding rivers and streams, while in other sectors the position of the aquifer water level is below the riverbed, reversing the behavior (i.e. rivers and streams feed aquifer). During the dry season, the behavior of the rivers remained the same, varying only in flow. Likewise, the sections in which the flow decreased drastically during the rainy season are the same ones that were completely dry in the dry season due to the decrease in the aquifer water level (Figure 3), which corroborates the influent character of the rivers and streams in these sectors.

\section{- Hydrogeological model}

In the Jacó area, two coastal aquifers have developed; one superficial, detrital, free, settled in the unconsolidated deposit, and a second fractured aquifer settled in the rocks of the Nicoya Complex (Figure 4). This fractured aquifer is free and deep in the mountains and, when it underlies the detrital aquifer in the alluvial plain, it can be confined in at least one sector of the central area of the plain, where the pressure reaches up to $1 \mathrm{~m}$ above ground level (drilling record of HE-134 and well 5-AyA) ${ }^{6}$

6 Nota N²4: se recomienda eliminar "del” en "Pozo 5 del AyA" y sustituir por Pozo 5-AyA con el objetivo de eliminar palabras conectoras cansan al lector en cualquier idioma. 
Figure 3. Mapping of differential gauging sites in the study area, Jacó Puntarenas, Costa Rica.

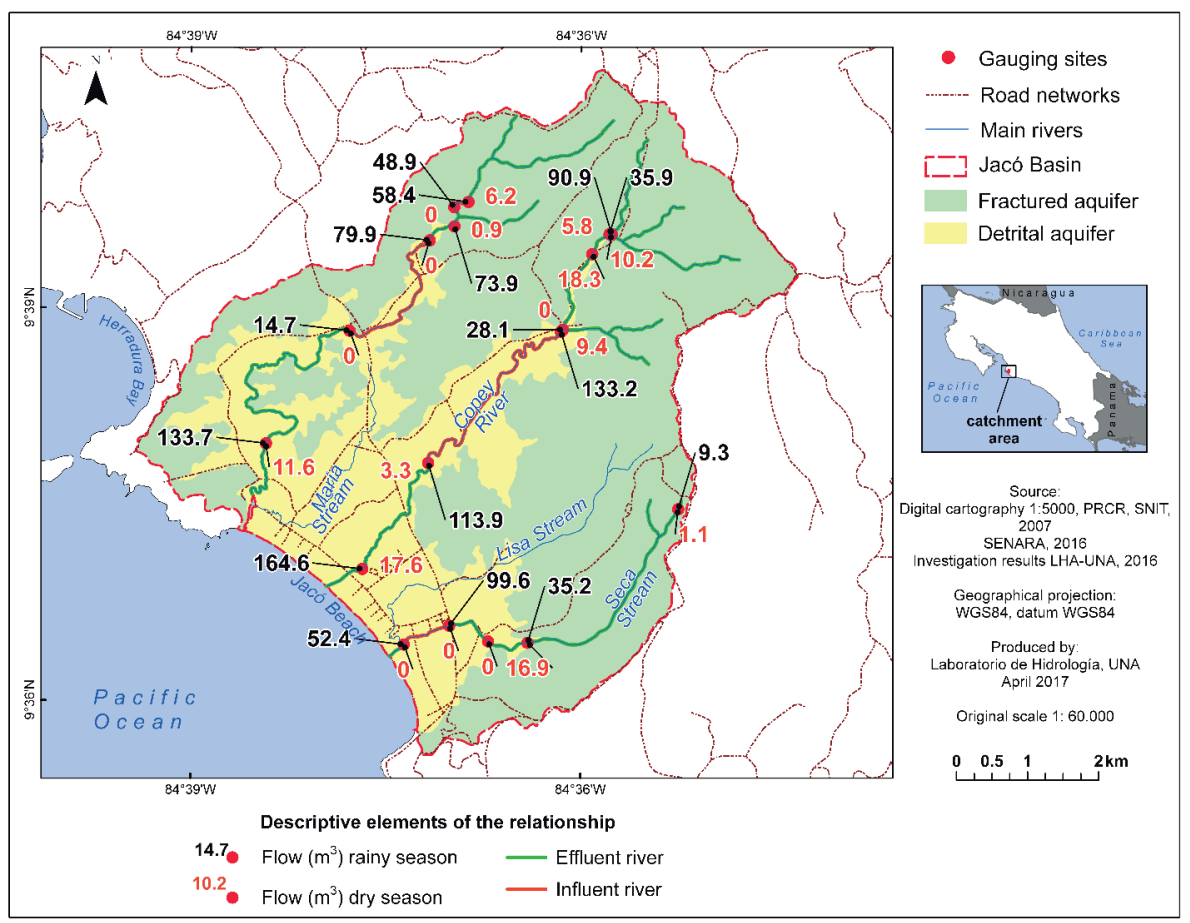

(profile 4, Figure 6). Groundwater in mountainous areas travels through basalts and sedimentary rocks; then, probably, a part is integrated into the groundwater of the unconsolidated deposit forming a single aquifer (profiles 1 and 2, Figures 5 and 6). Even if this aquifer was made up of two geological formations, unconsolidated materials and basalts below them, with different hydraulic conductivity and permeability values, it is likely for groundwater to maintain the same level due to the absence of an impermeable layer separating both formations, which is deduced from the drilling reports obtained from SENARA. The HE-134 well report indicated that when the well reached the fractured basalts, at $22 \mathrm{~m}$ depth, an upwelling occurred (profile 4, Figure 6). The declared upwelling in this, and in the well 5-AyA report, could be due to: a) the difference in permeability 
between the fractured and detrital formations, b) higher water pressure within the fractured material due to the effect of some clay lenses near the surface (profile 4, Figure 6) and/or, c) because the wells that reached the basalts are exposed to a greater hydraulic potential, for they reached depths with different equipotential lines to those wells that extract water from the detrital formation. In addition, profiles 1 and 2 (Figure 5) show that the topography of the basalts is very irregular and the groundwater level in these basalts is affected by steep slopes.

Figure 4. Study area hydrogeological map, Jacó, Puntarenas, Costa Rica.

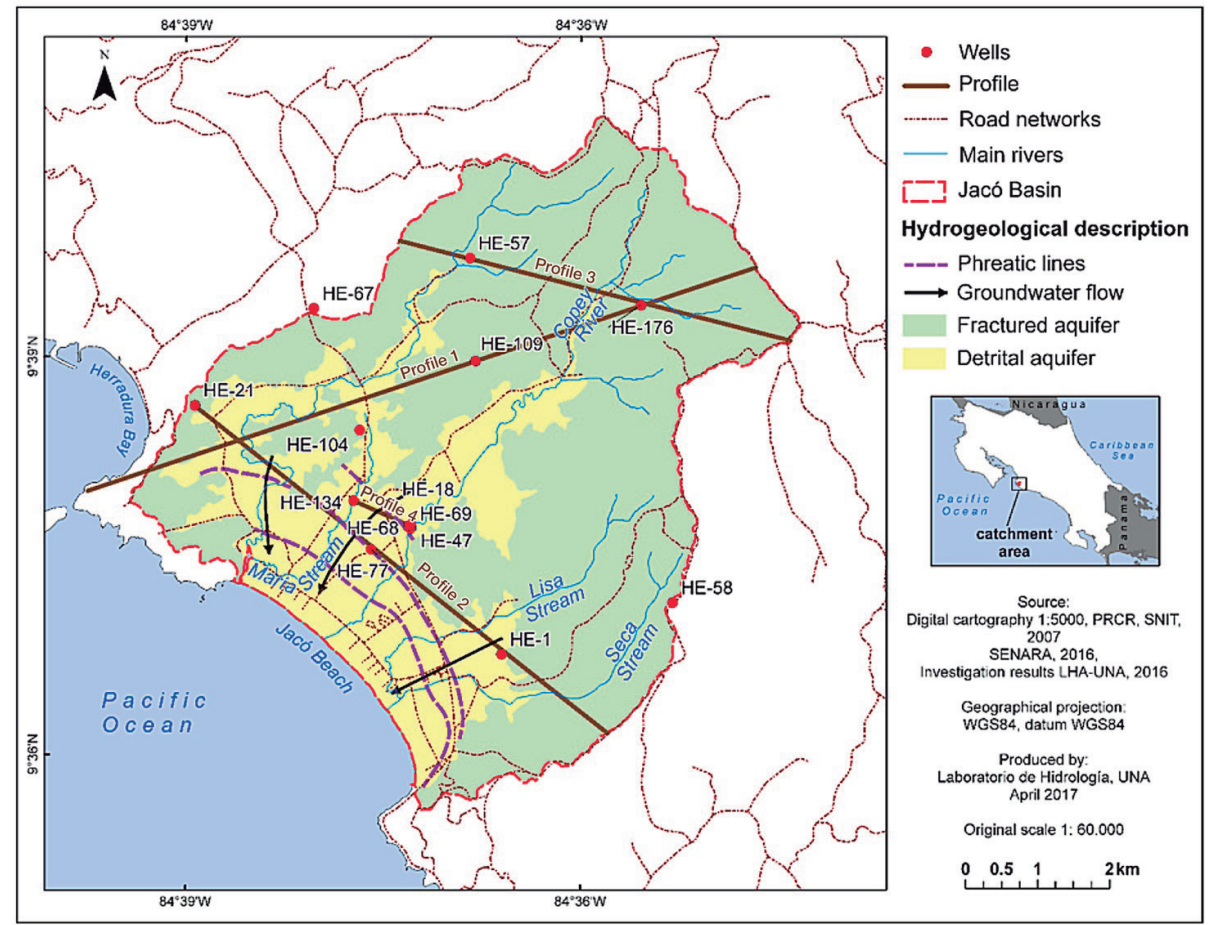


Alicia Gómez-Cruz - Helga Madrigal-Solis - Christian Núñez-Solís

Hazel Calderón-Sánchez - Pablo Jiménez-Gavilán

Hydrogeological vulnerability in Jacó coastal aquifers, Central Pacific, Costa Rica.

Figure 5. Hydrogeological profiles 1 and 3 located in the study area, Jacó, Puntarenas, Costa Rica.
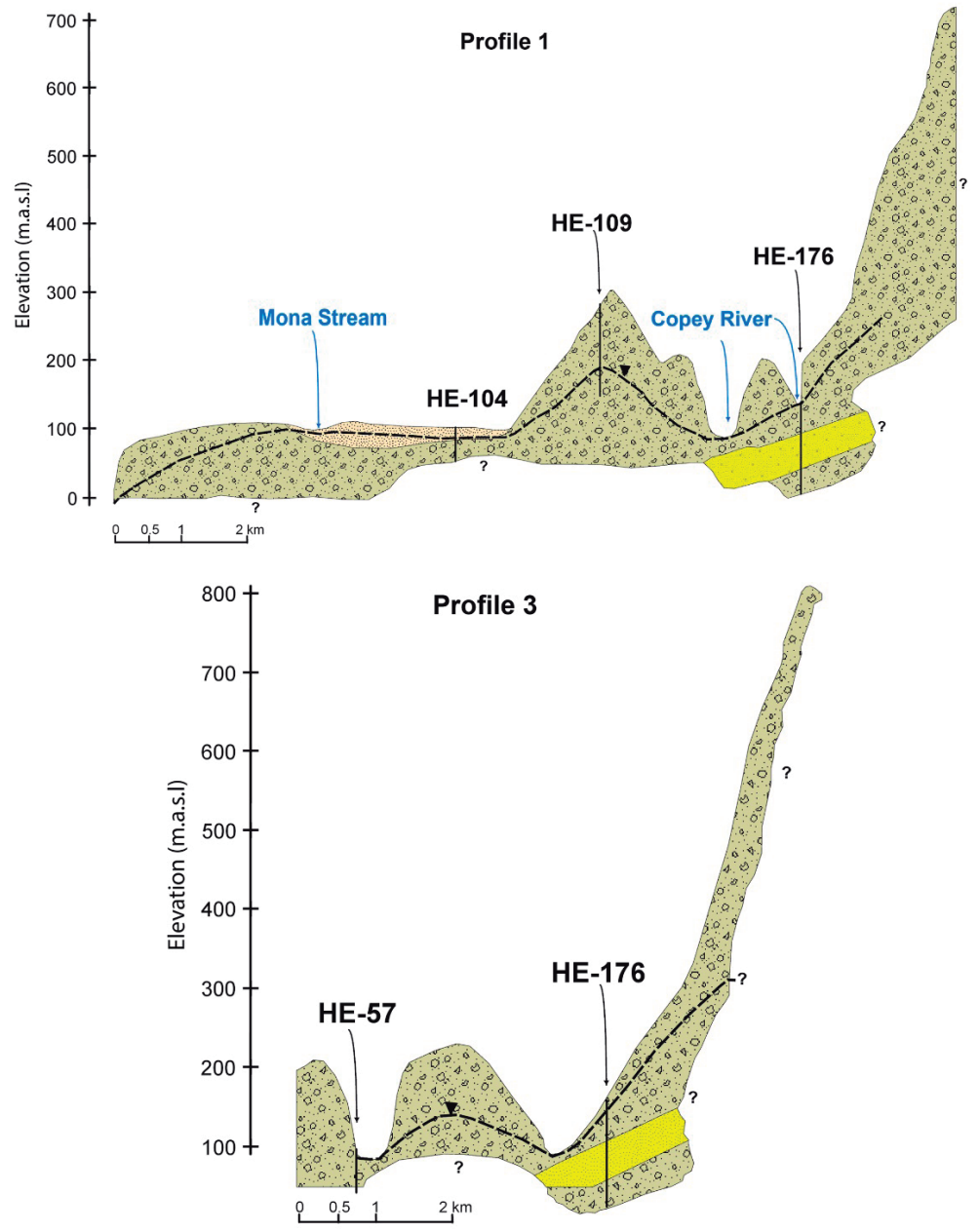

Map symbolization

Unconsolidated deposits $\quad \therefore$ Basaltic rocks
Clays


Figure 6. Hydrogeological profiles 2 and 4 in the study area, Jacó, Puntarenas, Costa Rica.
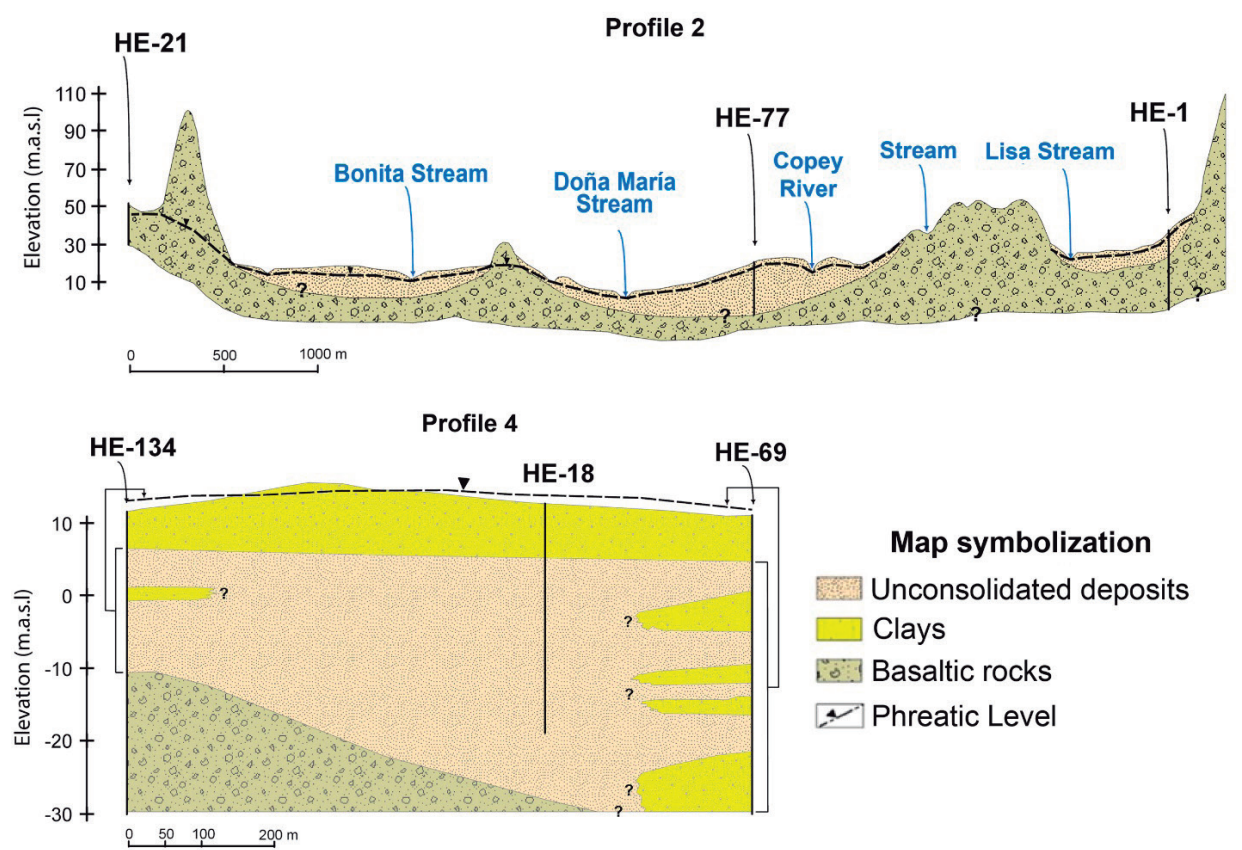

\section{- Jacó detrital aquifer.}

It is a free, detrital aquifer settled in unconsolidated materials such as sands, silts and gravels with a thin layer of soil. For those sectors where water level information is available, it reaches from 0.5 to $5 \mathrm{~m}$ deep, with equipotentials between 0.5 and 15 m.a.s.l (Figure 4). The hydraulic direction of this aquifer is to the southwest (SW) and the gradient is 0.01 . Another mechanism of recharge is via infiltration from river beds, as demonstrated by differential gauging assessment (Figure 3).

The aquifer discharge occurs naturally into rivers, and in some sectors (Figure 3), into the sea (Figure 4), as well as artificially by the water extraction from wells. In the alluvial plain no springs were found during field visits, nor are there records of their existence. Well exploitation flows indicate a variable productivity from 1 to $50 \mathrm{l} / \mathrm{s}$; those reporting the greatest extraction flows are wells that reached the fractured basalts. 
Alicia Gómez-Cruz - Helga Madrigal-Solis - Christian Núñez-Solís

Hazel Calderón-Sánchez - Pablo Jiménez-Gavilán

Hydrogeological vulnerability in Jacó coastal aquifers, Central Pacific, Costa Rica.

\section{- $\quad$ Fractured aquifer.}

This fractured aquifer, with a secondary permeability caused by fissures, has developed in lavas and the sedimentary rocks mentioned above, which compose the mountains surrounding the basin. To date, the fractured aquifer registered 19 wells, of which only 15 declared lithological data in their corresponding reports. The depth of groundwater level is variable because the wells themselves show variable depths and the resulting water level corresponds to an equilibrium level between the different producing layers. For example, well HE-109 has a depth of $105 \mathrm{~m}$ and a static level reported at $70 \mathrm{~m}$ depth, while well HE-58 has a depth of $180 \mathrm{~m}$ and a static level at $100 \mathrm{~m}$ depth. In the reports of wells HE-18, HE-19, HE-47, HE-68 and HE-134, all located in the central zone, upwelling was declared between 22 and $38 \mathrm{~m}$, where the fractured basalts are located (profile 4, Figure 6).

As for the productivity of the aquifer, the drilling reports obtained from the SENARA archives indicate very low flows, between 0.5 to 7 $1 / \mathrm{s}$, with very strong declines. In spite of not having performed pumping tests, this condition possibly reflects a low productivity aquifer as a result of low secondary permeability. Even though it was not possible to map equipotentials for this aquifer due to lack of information, it is likely that the flow is directed towards the alluvial zones, since the rocks that contain this aquifer are found in the hills bordering the plain. Subsequently, in the sector underlying the detrital aquifer, the water is integrated with the groundwater in the detrital aquifer, forming a single level and a single aquifer. Then, the flow is directed southwest towards the sea. However, this is an assumption based on topographic and geomorphological characteristics of the area (Figure 4).

\section{Hydrogeological vulnerability}

Once the hydrogeological conditions were defined, the vulnerabilities of the porous and fractured aquifers in the hill areas was estimated.

\section{Degree of hydraulic confinement (G Value)}

The detrital aquifer was assigned a value of 0.9 , as it is an aquifer with little coverage, that is, with a shallow vadose zone, as observed in the created profiles. For the fractured aquifer a value of 0.7 was estimated, corresponding to a free aquifer with coverage according to profiles 1, 2 and 3. (Figure 7). 


\section{Occurrence of the overlying substrate (Value $\mathbf{O}$ )}

Based on the lithological description in the drilling/perforation reports of the wells, a layer of clay-silt soil was identified in the alluvial aquifer zone, with a variable thickness between 0 and $14 \mathrm{~m}$, thus a value of 0.5 was estimated. In the mountains, the value is 0.6 and corresponds to fractured basaltic rocks (Figure 7).

\section{Distance to the groundwater level (D Value).}

In the detrital aquifer, the depth of the water level with respect to surface level is between 1 and $5 \mathrm{~m}$, so a value of 0.9 was assigned, while in the free fractured aquifer, in the mountainous areas, water was found between 20 and $50 \mathrm{~m}$ depth, corresponding to a value of 0.7 , although there are levels in some wells at greater depth (Figure 7).

Figure 7. Degree of hydraulic confinement (G), Occurrence of overlying substrate $(\mathrm{O})$ and Distance to groundwater level (D) of aquifers in the study area, Jacó, Puntarenas, Costa Rica.

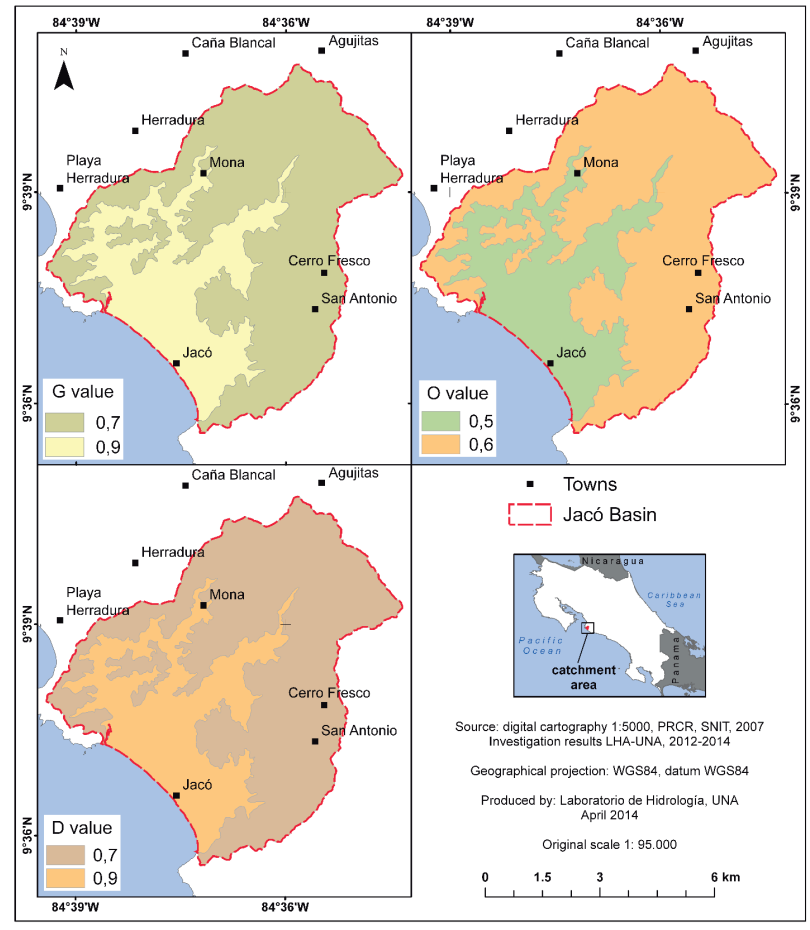


As a result, a medium degree of hydrogeological vulnerability was obtained in the area where the detrital aquifer is located, with a value of 0.41 (Figure 8). This sector represented $30.5 \%$ of the total study area, while the corresponding area of the fractured aquifer was classified with a low degree of hydrogeological vulnerability, with a value of 0.29 .

Figure 8. Proposed hydrogeological vulnerability of aquifers in the study area, Jacó, Puntarenas, Costa Rica.

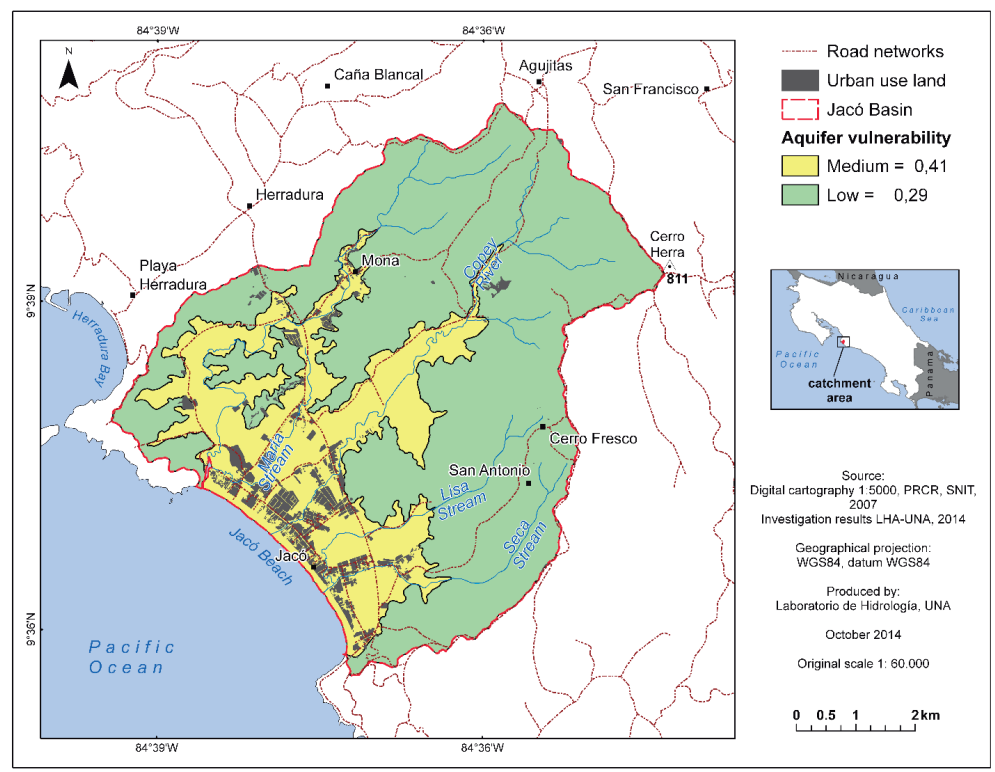

\section{Discussion}

Although the vulnerability to contamination depends on the natural attenuation capacity of the soil's profile to pollutants, it varies widely with the geological conditions that prevail near land surface. Among these conditions is the depth at which groundwater resides. This had important implications in designating a low vulnerability to the fractured aquifer, located in the mountains around the Jacó area, because the water level was found at depths greater than $50 \mathrm{~m}$. Low vulnerability aquifers are vulnerable to conservative contaminants, when these are regularly discharged or leached for long periods of time (Foster et al., 2007). According to Foster 
et al. (2013), an aquifer with low vulnerability can be vulnerable to the leaching of nitrates, highly saline liquids and organochlorine compou nds in dense, non-aqueous phase.

With respect to the aquifer on the alluvial plain, even though groundwater level is shallow, it was classified as moderate towards vulnerability to contamination. This is because the reports of the wells in this area indicate a surface layer of clays several meters thick, and even reveal intercalations of clays with the gravels inside the alluvial pack, which has given this aquifer a certain degree of protection against certain polluting substances. According to Foster et. (2007), aquifers with moderate vulnerability are those that are vulnerable to some pollutants when they are discharged or leached regularly. Even though there is a small sector within the aquifer where upwelling is reported, well reports do not indicate the depth at which this condition occurred and the groundwater levels pointed out in these reports represent the equilibrium levels between the confined sector and the more superficial detrital aquifer. For this reason, this sector was classified under the same vulnerability class as the rest of the detrital aquifer.

The inclusion of hydrogeological vulnerability in local planning programs (Plan Regulador, in Costa Rican legal jargon) by local governments in Costa Rica, would be a very useful tool for defining adequate activities to be developed within a municipal territory, and would allow the implementation of integrated water resource management processes. The implementation of the proposed vulnerability map must be accompanied with the application of a vulnerability matrix. In the case of Jacó, most of the urban developments, as well as the main productive and socioeconomic activities, are in the sector of moderate vulnerability of the study area. However, the local plan (Plan Regulador) for the development of the coastal zone of Jacó, which has not been approved to date, does not yet contemplate the vulnerability of the aquifer and allows a construction area per property equal to $70 \%$, which is not necessarily the appropriate measure for a moderate vulnerability sector, both for reasons of recharge and potentially polluting hydraulic load. Nor is there regulation that governs the size of future properties in non-urbanized areas within the district. In addition, it must be evaluated how many of the current properties meet the current construction area regulation and the required future control measures. 
The elaboration of vulnerability maps in the area evidenced a need for greater government investment to generate hydrogeological data, mainly through the installation of more piezometers around the Nicoya Complex area. This indication is necessary for any method of assessing hydrogeological vulnerability (Foster et al., 2013). Due to the scarcity of hydrogeological data in the study area, part of the information must be extrapolated from other sectors. This occurred in sectors that are geologically associated with the rocks of the Nicoya Complex, with little data on the depth of the water level and lithology. Fortunately, the largest proportion of zones with little information are located in areas with slopes greater than $40 \%$ hence receiving protection already typified in the current Forestry Law and, therefore, are not susceptible to being developed. On the other hand, due to the scarcity of information available in the area, the methodology that is best suited for this study was that of the GOD method. Similarly, it is recommended to utilize, if more information is generated, other methods of greater accuracy, such as DRASTIC, proposed by Aller et al. (1987), among others. However, DRASTIC method tends to underestimate the vulnerability of fractured aquifers (Foster et al., 2007), and other more complex methods require greater investment in terms of data input generation, such as percolation rate or aquifer recharge rate. In addition, according to Foster et al. (2013), the most complex methods do not necessarily afford the most realistic vulnerability maps.

In Costa Rica, land use plans for territorial ordering do not take into account the threat and risk of contamination but only incorporate hydrogeological vulnerability mapping as a tool for managing the groundwater resource. The pollution risk map, by integrating the threat of contamination and aquifer vulnerability, would allow the identification of conflict zones and the territory regulation, with the purpose of designing or taking regulatory corrective measures for the protection of groundwater.

\section{Recommendations}

Taking into account the estimated level of vulnerability, a series of soil management and protection recommendations were generated for the study area. Even with limited availability of lithological information and lack of infiltration testing for the fractured aquifer, it is recommended to 
pursue several protective actions as precautionary measures until a better understanding exist of the unsaturated zone over the fractured aquifer.

This is how, for the alluvial plain, which was classified as a moderate hydrogeological vulnerability zone, the installation of a sanitary sewer system having a treatment system is justified due to potential leaching of polluting substances from septic tanks and latrines. It is recommended that this measure be introduced gradually with the support of the local government, $A y A$ and the Cantonal Council for Interinstitutional Coordination ( $C C C I$ ) of Jacó. Moreover, improved wastewater treatment plants are mandatory for high-impact hotel, tourism and industrial activities, in accordance with the concept of harmony with the environment, aimed at ecotourism and environmental sustainability.

Furthermore, it is recommended that for the sector of moderate vulnerability (i.e. detrital aquifer), land use status be changed from pasture and cropland to urban if the previously mentioned sewage water disposal indications are met. In addition, it is recommended that the properties possess a minimum area of $300 \mathrm{~m}^{2}$, with a maximum construction area equivalent to $50 \%$ of the total area to avoid land surface impermeabilization and favor aquifer recharge. If the cultivation zones in the detrital aquifer area are conserved, it is recommended to encourage improved agricultural management practices, such as the rational use of agrochemicals, organic agriculture, crop rotation and controlled cropping systems to decrease soil utilization burden (soil relaxation) as well as reforestation projects. In this zone, landfills, quarries and/or pits are not recommended.

Likewise, in the sector of low vulnerability, overlying the fractured aquifer, regulations can be more flexible and permissive. As for urban development, we recommend properties with a minimum $250 \mathrm{~m}^{2}$ and with a maximum construction area of $50 \%$, as long as the terrain has a slope of less than $40 \%$. As in the areas of moderate vulnerability, agriculture and grazing, must follow appropriate soil management practices, and where possible, reforestation and organic agriculture should be encouraged. Tourism and hotel activities should be conceptually focused towards ecotourism. It is recommended that the following infrastructure and activities be allowed: landfills (of suitable design), pits, quarries and industry with improved treatment plants. Land use recommendation for terrains possessing a slope 
greater than $40 \%$ is as forest land as is currently mandated under Costa Rica Forestry Law to among other things this minimizes erosion.

Finally, it is recommended to implement or continue executing other integral water resource management tools: economic incentives to promote a shift towards activities of less polluting potential in zones with moderate and high vulnerability; groundwater quality monitoring networks; and implementation of social awareness programs derived from joint watershed management agreements between cantons and localities, supported by universities, municipalities, government and private enterprise.

\section{References}

Andreo, B., Vadillo, I., Carrasco, F., Neukum, C., Jiménez, P., Goldscheider, N., Hötzl, H., Vías, J.M., Pérez, I. y Göppert, N. (2004). Precisiones sobre el funcionamiento hidrodinámico y la vulnerabilidad a la contaminación del acuífero kárstico de la Sierra de Líbar (provincias de Málaga y Cádiz, Sur de España) a partir de un ensayo de trazadores. Revista de la Sociedad Geológica de España, 17(3-4): 187-197.

Albinet, M. y Margat, J. (1970) Cartographie de la vulnerabilite a la pollution des nappes d'eau souterraine [Contamination vulnerability mapping of groundwater]. Bulletin de la Bureau de Recherches Géologiques et Minieres. Segunda serie 3(4):13-22.

Agudelo, C. (2005). Diagnóstico de las aguas subterráneas en las hojas Tárcoles, Herradura y Candelaria. Servicio Nacional de Aguas Subterráneas, Riego y Avenamiento. pp. 35. SENARA, San José. [Informe interno].

Aller, L., Bennett, T., Lehr, J., Petty, R. y Hackett, G. (1987). DRASTIC: A standardized system for evaluating geroundwater pollution potential using hydrogeologic settings. Environmental Protection Agency Report 600/2-87-035. Washington, D.C.

Arias, O. (2003). Redefinición de la Formación Tulín (MaastrichtianoEoceno Inferior) del Pacífico Central de Costa Rica. Revista Geológica de América Central, 28:47-68.

Arias, M. y Morera, S. (2002). Evaluación del acuífero de Jaco, cantón de Garabito, Provincia de Puntarenas. Servicio Nacional de Aguas Subterráneas, Riego y Avenamient. pp.15, SENARA, San José [Informe interno]. 
Barrantes, G. (2004). Disponibilidad del recurso hídrico y sus implicaciones para el desarrollo en Costa Rica. -25 págs. Undécimo Informe Estado de la Nación en Desarrollo Humano Sostenible, Programa Estado de la Nación. San José, Costa Rica. [Informe interno].

Baumgartner, P. (1984). El Complejo Ofiolitico de Nicoya (Costa Rica): Modelos estructurales analizados en función de las edades de los radiolarios (Calloviense a Santoniense). Citado en: Sprechmann, P. (1984). Estratigrafía del Complejo de Nicoya. En: Sprechmann, P. (Ed.). Manual de geología de Costa Rica, (115-123). Volúmen1: Estratigrafía. Editorial de la Universidad de Costa Rica. San José, Costa Rica.

Barberá, J. A. y Andreo, B. (2015). Hydrogeological processes in a fluviokarstic area inferred from the analysis of natural hydrogeochemical tracers. The case study of eastern Serranía de Ronda (S Spain). Journal of Hydrology, 523: 500-514.

Denyer, P. y Alvarado, G. (2007), Mapa Geológico de Costa Rica. - Escala 1:400000, DGM-ECG-UCR, San José, Costa Rica.

Denyer, P., Montero, W. y Alvarado, G. (2003). Atlas tectónico de Costa Rica. - Escala 1: 500000, EUCR, San José, Costa Rica.

Estado de la Nación (2007). Decimotercer Informe Estado de la Nación en Desarrollo Humano Sostenible. Programa Estado de la Nación. San José, Costa Rica [Inf. interno]. pp. 437.

Foster, S. (1992). Unsustainable development and irrational exploitation of groundwater resources in developing nations an overview. $I A H$ Hydrogeology Selected Papers. Heise, Hannover. 3: 321-336.

Foster, S. e Hirata, R. (1991). Determinación del riesgo de contaminación de aguas subterráneas, una metodología basada en datos existentes [2a ed.]. - 90 págs. CEPIS, Centro Panamericano de Ingeniería Sanitaria y Ciencias del Ambiente, Lima, Perú.

Foster, S. e Hirata, R. (1988). Groundwater pollution risk assessment: a methodology using available data. WHO-PAHO-CEPIS, Lima.

Foster, S., Hirata, R. y Andreo, B. (2013). The aquifer pollution vulnerability concept: aid or impediment in promoting groundwater protection? Hydrogeology Journal, 21, 1389-3922 p. 
Foster, S., Hirata, R., Gomes, D., D'Elia, M. y Paris, M. (2007). Protección de la Calidad del Agua Subterránea. Banco Mundial, Washington, D.C. (pp. 115).

INEC (2012). Resultados generales. Censo Nacional de Población y VI de Vivienda 2011. Instituto Nacional de Estadística y Censos. San José, Costa Rica. Recuperado: www.inec.go.cr [Consulta 4/03/2015].

Kuypers, E. P. (1980). The geologic history of the Nicoya Ophiolite Complex, Costa rica, and its geotectonic significance. Amsterdam, The Netherlands. Tectonophysics 68(3/4): 233-255. Citado en: Sprechmann, P. (1984). Estratigrafía del Complejo de Nicoya. En: Peter Sprechmann (Ed.). Manual de geología de Costa Rica. Volúmen1: Estratigrafía. Editorial de la Universidad de Costa Rica. San José, Costa Rica. pp.320.

Llamas, M.R. y Custodio, E. (2003). Intensive use of groundwater: a new situation which demands proactive actions. En: Llamas, M.R., Custodio, E. (Eds.), Intensive Use of Groundwater, Challenges and Opportunities (13-34). A.A. Balkema Publishers. Lisse, Países Bajos.

Orozco, R. (2015). Propuesta de manejo de uso y cobertura de la tierra para la reducción del riesgo de contaminación del acuífero costero Jacó, Pacifico Central, Costa Rica. 56 p. (Tesis de Licenciatura Universidad Nacional), Heredia, Costa Rica.

PRCR (2007). Proyecto de Regularización Catastral y Registral. Cartografía digital y ortofoto. Escala 1:50000. Instituto Geográfico Nacional. San José, Costa Rica.

Reynolds, J. y Fraile, J. (2002): Presente y futuro de las aguas subterráneas en el Valle Central. En: Reynolds, J. (ed.): Manejo Integrado de Aguas Subterráneas. EUNED. San José, Costa Rica. pp. 313. 